Огляди літератури, оригінальні дослідження, погляд на проблему

УДК 616.1:[616-008.64:577.175.6]-02-07-055.1

DOI 10.11603/1811-2471.2018.v0.i1.8475

\title{
ОЦІНКА СЕРЦЕВО-СУДИННОГО РИЗИКУ В ЧОЛОВІКІВ ІЗ ГІПЕРТОНІЧНОЮ ХВОРОБОЮ НА ТЛІ АНДРОГЕННОГО ДЕФІЦИТУ
}

\author{
๑В. А. Візір, А. С. Садомов, О. В. Насоненко \\ Запорізький державний медичний університет
}

РЕзЮМЕ. Вступ. Дані численних досліджень вказують на зв'язок низького рівня тестостерону у чоловіків із окремими факторами ризику ССЗ (ожиріння, цукровий діабет 2 типу, метаболічний синдром тощо). Статистичні підходи передбачають розрахунок кардіоваскулярного ризику для загальної популяції, а використання їх для оцінки ризику у чоловіків із дефіцитом тестостерону в літературі не описане.

Мета дослідження - на підставі порівняльного аналізу ряду шкал (Фремінгемська, SCORE та PROCAM) визначити найбільш валідну для оцінки серцево-судинного ризику у чоловіків із гіпертонічною хворобою на тлі андрогенного дефіциту.

Матеріал і методи. Дослідження включало 50 пацієнтів чоловічої статі із встановленим діагнозом гіпертонічної хвороби II стадії та 11 практично здорових осіб, що увійшли до контрольної групи. У всіх учасників дослідження, поряд із загальноклінічним обстеженням, визначали параметри ліпідного профілю та загальний тестостерон (ЗТ) сироватки крові, оцінювали серцево-судинний ризик за Фремінгемською шкалою (ФШ), шкалами SCORE та PROCAM. Залежно від рівня 3Т обстежені були поділені на 2 групи: 1 група (n=27) - 3 дефіцитом 3T, 2 група ( $n=23)$ з нормальним рівнем 3 Т.

Результати. При аналізі серцево-судинного ризику учасників дослідження встановлено, що за ФШ до групи високого ризику належали 55,6 \% чоловіків 1 групи та 43,5 \% осіб 2 групи, за шкалою PROCAM ризик вище 20 \% мали 66,7 \% та 39,1 \% пацієнтів відповідно. Частка обстежених, що мали високий ризик за шкалою SCORE, склала 51,8 \% серед чоловіків 1 групи та 39,1 \% - 2 групи. Значущих відмінностей між ризиком за ФШ та SCORE між групами 1 та 2 виявлено не було, тоді як різниця між вказаними групами була статистично вірогідною за шкалою PROCAM. Кореляційний аналіз продемонстрував тенденцію до негативного зворотного зв'язку між серцевосудинним ризиком та рівнем 3Т, при цьому статистично значущою кореляція була лише між ЗТ та ризиком за шкалою PROCAM $(p<0,05)$.

Висновки. Використання шкали PROCAM є найбільш обґрунтованим для категоризації ризику у когорті чоловіків із гіпертонічною хворобою, асоційованою з андрогенним дефіцитом.

КлючовІ слОВА: гіпертензія; тестостерон; холестерин.

Вступ. Провідне місце у структурі причин загальної смертності залишається за серцево-судинними захворюваннями (ССЗ), що складають більше 50 \% усіх смертей у багатьох країнах з середнім рівнем доходу та менше $30 \%$ у розвинених державах із високим рівнем доходу в Західній Європі. Аналіз показників смертності від IXC, стандартизованих за віком, демонструє значні відмінності між країнами з високим і середнім рівнями доходу. Поширеність ССЗ в Україні залишається високою та складає більше 500 на 100000 населення серед жінок та більше 800 на 100000 серед чоловіків [1].

У розвитку та прогресуванні ССЗ значна роль належить факторам ризику. Численні індивідуальні характеристики сприяють розвитку ССЗ, включаючи стать, вік, концентрацію ліпідів у крові, підвищений артеріальний тиск, порушення толерантності до глюкози, ожиріння, куріння тощо. Серед причин смертності впродовж останніх років в Україні перше місце незмінно займають хвороби системи кровообігу $(30,67 \%$ станом на 2016 рік), відзначається також зростання загального серцево-судинного ризику, особливо у чоловічій популяції [2].
Численні дослідження вказують на зв'язок низького рівня тестостерону у чоловіків із такими відомими факторами ризику ССЗ та смертності, як ожиріння, цукровий діабет 2 типу та метаболічний синдром. Дослідження минулих років, що включали чоловіків та жінок зіставних вікових діапазонів, продемонстрували зв'язок підвищеного рівня тестостерону з виникненням ССЗ. Недавні масштабні когортні мета-аналізи свідчать про те, що низький рівень тестостерону пов'язаний із розвитком IXC [3]. Цукровий діабет 2 типу та ожиріння також пов'язані з тестостероновим дефіцитом і сприяють підвищенню ризику СС3 [4]. Алкоголь та куріння $\epsilon$ додатковими чинниками, що збільшують частоту ССЗ, також вони викликають зниження рівня тестостерону у чоловіків.

Серед модифікованих факторів ризику АГ вважають найважливішим у розвитку IXC і цере6роваскулярних подій. Що стосується впливу чоловічих статевих гормонів на артеріальний тиск (АТ), то відомо, що тестостерон може впливати на АТ через кілька механізмів, включаючи прямий вплив на серце, нирки та судини, а також непрямі ефекти, опосередковані нейрогормональними факторами [5]. Продемонстрований модулювальний 
Огляди літератури, оригінальні дослідження, погляд на проблему

ефект андрогенів на розвиток та тяжкість АГ у деяких генетичних та негенетичних моделях та деяких формах вторинної гіпертензії у людей [6], проте в численних епідеміологічних дослідженнях отримані суперечливі результати щодо взаємозв'язку між андрогенами та есенціальною АГ. Деякі дослідження показали зниження рівнів андрогенуупацієнтівз АГ, порівняноз нормотензивними суб'єктами [7], тоді як інші дослідження не виявили суттєвої різниці в цьому відношенні. Відмінності в отриманих результатах можуть бути пов'язані з такими чинниками як неоднорідність досліджуваних груп, різниця в використовуваних методиках і відсутність контролю щодо віку, конституційних особливостей, куріння, вживання наркотиків та анамнезу попередньої сексуальної дисфункції.

Для оцінки індивідуального «глобального» ризику ССЗ у рутинній клінічній практиці розроблені численні статистичні підходи - Фремінгемська шкала, шкали SCORE, PROCAM та інші. Використання вказаних методик передбачене для розрахунку кардіоваскулярного ризику для загальної популяції, а досліджень з оцінки ризику для паці$\epsilon$ нтів із АГ та коморбідними станами на сьогоднішній день недостатньо. Порівняльний аналіз наявних підходів для оцінки серцево-судинного ризику у чоловіків із АГ та андрогенним дефіцитом у літературі не описаний, а дані про вплив чоловічих статевих гормонів на ризик серцево-судинних подій залишаються суперечливими.

Мета дослідження - на підставі порівняльного аналізу ряду шкал (Фремінгемська, SCORE та PROCAM ) визначити найбільш валідну для оцінки серцево-судинного ризику у чоловіків із гіпертонічною хворобою на тлі андрогенного дефіциту.

Матеріал і методи дослідження. Дослідження включало 50 пацієнтів чоловічої статі із встановленим діагнозом гіпертонічної хвороби II стадії, що перебували на стаціонарному лікуванні у кардіологічному відділенні КУ «Міська лікарня № 7» м. Запоріжжя, та 11 практично здорових осіб, що увійшли до контрольної групи. Хворих на цукровий діабет, ожиріння, серцеву недостатність III-IV функціональних класів (NYHA), пацієнтів з серцево-судинними подіями в анамнезі, онкопатологією, первинним гіпогонадизмом до дослідження не включали.

Усі чоловіки, що дали письмову згоду на участь у дослідженні, підлягали загальноклінічному обстеженню. Рівень загального холестерину (3XC), тригліцеридів (ТГ), ліпопротеїдів високої (ЛПВЩ) та низької щільності (ЛПНЩ) визначали натще з використанням біохімічного автоматичного аналізатора Prestige 24і (Японія).

Для оцінки андрогенного статусу у всіх учасників дослідження визначали рівень загального тестостерону (3Т) сироватки крові методом імуноферментного аналізу з використанням наборів реактивів Monobind Inc. (США) згідно з інструкцією виробника. Забір крові виконували між 7:00 та 11:00 ранку [8]. Залежно від рівня 3Т обстежені були поділені на 2 групи: 1 група (n=27) - 3 дефіцитом тестостерону, 2 група ( $n=23)$ - з рівнем 3 Т у межах референтних значень.

У всіх осіб, включених у дослідження, оцінювали серцево-судинний ризик за Фремінгемською шкалою (ФШ), шкалами SCORE та PROCAM. Фремінгемська шкала $\epsilon$ мультиваріантною, що передбачає 10-річний ризик розвитку серцево-судинних подій (IXC, інсульт, захворювання периферійних артерій або серцева недостатність) з урахуванням статі, віку, загального холестерину (3ХC) та холестерину ліпопротеїнів високої щільності (ЛПВЩ), систолічного артеріального тиску (АT), застосування антигіпертензивних препаратів, куріння та наявності діабету (ризик менше $10 \%$ вважали низьким, 10-20\% - середнім, більше $20 \%$ - високим) [9]. Для розрахунку ризику за ФШ використовували онлайн-ресурс https:// www.framinghamheartstudy.org.

Шкала PROCAM враховує вік, холестерин ліпопротеїнів низької щільності (ЛПНЩ), ЛПВЩ, тригліцеридів (ТГ), статус куріння, систолічний АТ, сімейний анамнез інфаркту міокарда у ранньому віці та цукровий діабет [10]. Розрахований результат менше 10 \% вважають низьким, 10-20\% - середнім, вище $20 \%$ - високим 10-річним ризиком коронарних подій. Шкала доступна в інтерактивному вигляді (http://cmd-taskforce.org/riskassessment/).

Шкалу SCORE застосовують для прогнозування 10-річного ризику фатальних кардіоваскулярних захворювань. Модель включає стать, вік, систолічний АТ, 3XС і куріння. Ризик серцево-судинної смерті впродовж 10 років 0-4 \% вважають за низький, 5-9 \% - середній, вище $10 \%$ - високий [11]. Для розрахунку ризику за шкалою SCORE використовували онлайн-калькулятор HeartScore, запропонований Європейським товариством кардіології та Європейською асоціацією превентивної кардіології (https://heartscore.escardio.org).

Для аналізу отриманих результатів використовували методи параметричної і непараметричної статистики із застосуванням пакетів Excel for Windows. Результати представлені у вигляді медіани та інтерквартильного розмаху (25-й і 75-й перцентилі). Для оцінки зв'язку тестостерону 3 ризиком ССЗ використовували кореляційний коефіцієнт Пірсона. Вірогідність різниці у разі нормального розподілу оцінювали за допомогою критерію Стьюдента, різницю вважали значущою при $\mathrm{P}<0,05$. 
Огляди літератури, оригінальні дослідження, погляд на проблему

Дослідження проводили із дотриманням вимог Гельсінської декларації.

Результати й обговорення. Характеристика обстежених хворих наведена у таблиці 1. Середній вік пацієнтів 1 групи склав 57 років [48; 67], 2 групи - 55 років [46; 64], контрольної групи 53 роки $[45 ; 65]$
Статично вірогідні відмінності виявлені між пацієнтами 1 і 2 груп та групою контролю за такими показниками як середній САТ та ДАТ, ЗХС, ЛПНЩ, ЛПВЩ та ТГ, тоді як пацієнти 1 та 2 груп значуще відрізнялись між собою за рівнями 3ХC, ЛПнЩ та ТГ. Відносна частка курців у обстежених групах не відрізнялась (табл. 1).

Таблиця 1. Характеристика обстежених осіб

\begin{tabular}{|l|c|c|c|}
\hline \multicolumn{1}{|c|}{ Характеристики } & $\begin{array}{c}1 \text { група (пацієнти з ГX } \\
\text { та андрогенним дефіцитом), n=27 }\end{array}$ & $\begin{array}{c}2 \text { група (пацієнти з ГХ } \\
\text { та нормальним рівнем 3Т), n=23 }\end{array}$ & $\begin{array}{c}\text { Контрольна група, } \\
\mathrm{n}=11\end{array}$ \\
\hline САТ & $146[140,5 ; 151]^{*}$ & $144[142 ; 150]^{*}$ & $126[120,5 ; 138]$ \\
\hline ДАТ & $96[87 ; 104]^{*}$ & $96[83 ; 99]^{*}$ & $83[76 ; 88]$ \\
\hline 3 ХС & $4,94[4,34 ; 5,84]^{*}$ & $4,37[3,58 ; 5,14]^{*} \#$ & $4,18[3,91 ; 4,49]$ \\
\hline ЛПНЩ & $3,79[3,29 ; 4,64]^{*}$ & $3,17[2,70 ; 3,78]^{*} \#$ & $3,06[2,56 ; 3,53]$ \\
\hline ЛПВЩ & $1,04[0,95 ; 1,27]^{*}$ & $1,06[0,89 ; 1,20]^{*}$ & $0,96[0,74 ; 1,29]$ \\
\hline ТГ & $2,59[2,13 ; 3,42]^{*}$ & $2,48[2,14 ; 2,83]^{*} \#$ & $2,07[1,69 ; 2,52]$ \\
\hline ІМТ & $28,21[24,32 ; 29,98]$ & $27,54[23,25 ; 28,35]$ & $27,73[23,78 ; 29,71]$ \\
\hline Куріння, \% & $11(40,74 \%)$ & $9(39,13 \%)$ & $4(36,36 \%)$ \\
\hline $\begin{array}{l}\text { Обтяжений сімейний } \\
\text { анамнез, \% }\end{array}$ & $18(66,67 \%)$ & $16(69,57 \%)$ & $2(18,18 \%)$ \\
\hline
\end{tabular}

Примітка: *p<0,05 у порівнянні з контрольною групою, \# p<0,05 у порівнянні з групою 1.

Рівень загального тестостерону статистично вірогідно відрізнявся у пацієнтів усіх груп та ста- новив відповідно $1,56[0,87 ; 1,92], 3,55[2,86 ; 3,86]$ та $3,99[3,80 ; 8,75]$ нг/мл (рис. 1).

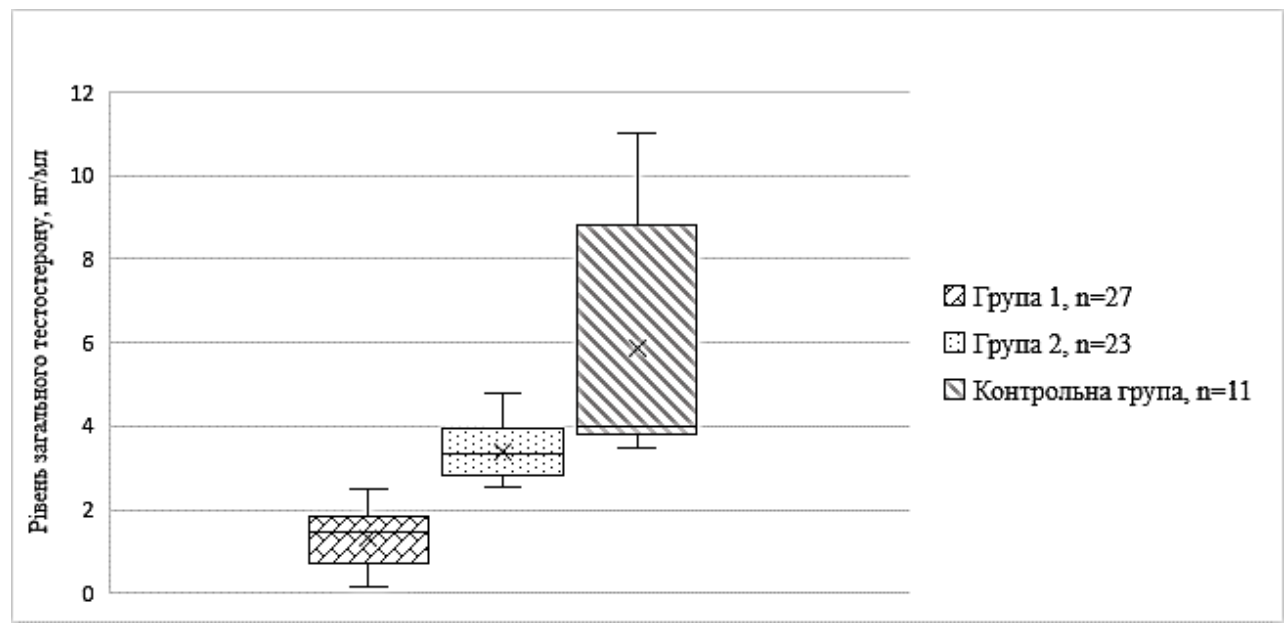

Рис. 1. Рівень загального тестостерону сироватки крові у обстежених осіб.

При аналізі серцево-судинного ризику учасників дослідження встановлено, що за ФШ до групи високого ризику належали 55,6 \% чоловіків зі зниженим рівнем тестостерону та $43,5 \%$ осіб без андрогенного дефіциту. Схоже співвідношення спостерігалось і при розрахунку за шкалою PROCAM - ризик вище $20 \%$ мали $66,7 \%$ та $39,1 \%$ пацієнтів відповідно. Частка обстежених, що мали високий ризик за шкалою SCORE, склала 51,8\% серед чоловіків 1 групи та 39,1\% - 2 групи.

Як видно з рисунка 2, значущих відмінностей між розрахунковим ризиком за ФШ та SCORE між групами 1 та 2 виявлено не було, тоді як різниця між чоловіками зі зниженим рівнем тестостерону та такими без дефіциту андрогенів була статистично вірогідною за шкалою PROCAM (медіана ризику $42,13 \%[23,45 ; 47,14]$ та $8,05 \%[6,47 ; 26,91]$ у 1 та 2 групах відповідно).

Дослідження кореляційних зв'язків між рівнем загального тестостерону та ризиком серцево-судинних подій (табл. 2) продемонструвало тенденцію до негативного зворотного зв'язку між вказаними параметрами, що виявився статистично значущим лише для кореляції між рівнем тестостерону та ризиком за шкалою PROCAM $(p<0,05)$. 
Огляди літератури, оригінальні дослідження, погляд на проблему

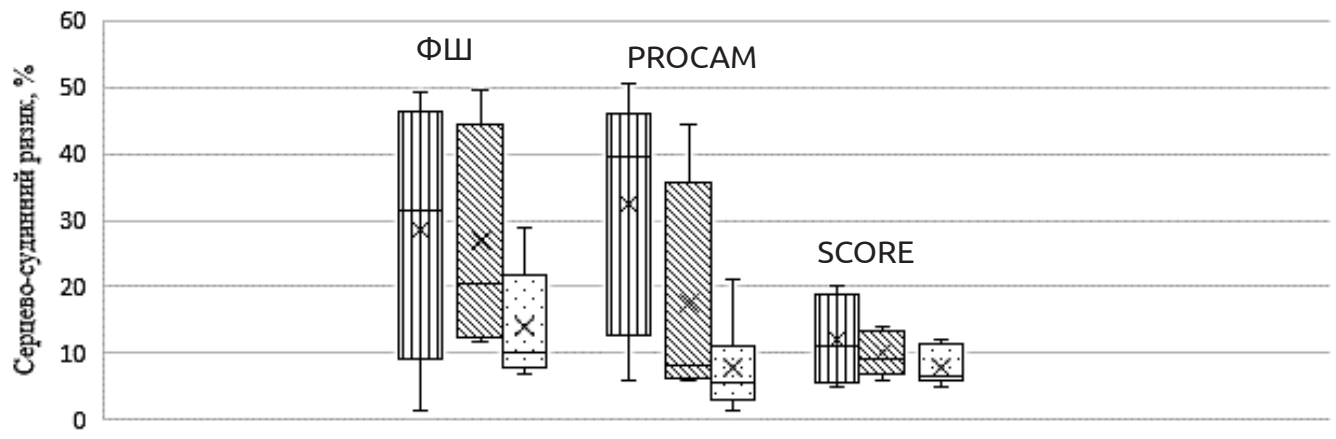

Рис. 2. Оцінка серцево-судинного ризику в досліджуваних групах.

Таблиця 2. Кореляційний взаємозв'язок між рівнем загального тестостерону та ризиком серцево-судинних подій

\begin{tabular}{|l|c|c|}
\hline \multicolumn{1}{|c|}{ Змінні } & Коефіцієнт кореляції, $r$ & P \\
\hline Кардіоваскулярний ризик за ФШ & $-0,59$ & 0,24 \\
\hline Кардіоваскулярний ризик за шкалою PROCAM & $-0,63$ & 0,02 \\
\hline Кардіоваскулярний ризик за шкалою SCORE & $-0,60$ & 0,11 \\
\hline
\end{tabular}

У літературі дані про взаємозв'язок андрогенів із серцево-судинним ризиком, захворюваністю та смертністю різняться. В нашому дослідженні, де 10-річна ймовірність настання кардіоваскулярних подій розраховувалась з використанням ФШ, шкал SCORE та PROCAM для хворих на ГX чоловічої статі із нормальним та зниженим рівнями тестостерону, показане підвищення серцевосудинного ризику у чоловіків із андрогенним дефіцитом, порівняно з такими з нормальним рівнем андрогенів.

Експериментальні випробування, проведені для вивчення зв'язку між концентрацією циркулюючого ендогенного тестостерону і ризиком СС3, продемонстрували суперечливі результати. Malkin i співавт. [12] оцінили поширеність біохімічно підтвердженого дефіциту тестостерону (використовуючи концентрацію і загального, і біодоступного тестостерону) у 24 \% серед чоловіків з IXC. Автори також описали вищі показники кардіоваскулярної та загальної смертності серед чоловіків з низькими рівнями андрогенів, порівняно з чоловіками, які не мають андрогенного дефіциту. Результати дослідження MrOS підтвердили, що чоловіки, у яких рівень тестостерону знаходився у вищому квартилі, мали нижчий рівень серцево-судинних подій протягом 5 років спостереження [13]. Үеар та співавт. виявили, що висока концентрація тестостерону і його метаболіту дигідротестостерону були пов'язані з нижчим ризиком інсульту протягом 6,5 років спостереження, але рівні андрогенів не асоціювалися з диференційованим ризиком інфаркту міокарда [14]. У про- спективному аналізі Laughlin та співавт. з залученням 794 чоловіків віком від 50 до 91 року [15] повідомлялося про підвищення серцево-судинного ризику, пов'язаного з низьким рівнем тестостерону та коефіцієнтом ризику $2,29(1,25-4,20)$ після спостереження впродовж 11,8 років. Подібні результати мало і дослідження Chock і співавт., що включало 1479 пацієнтів - ризик за ФШ був зворотно асоційований як із загальним тестостероном, так і з вільним тестостероном [16]. Схожі припущення дозволяє висловити і наше дослідження, адже у групі чоловіків із низьким рівнем тестостерону виявлений найвищий серцево-судинний ризик за всіма трьома шкалами, які використовували для його розрахунку. Статистично значущим асоціативний зв'язок тестостерону виявився тільки з показником за шкалою PROCAM. Оскільки вказана шкала для оцінки ризику використовує рівень тригліцеридів, лПнЩ, лПвЩ, а не тільки рівень загального холестерину (як SCORE) або загального холестерину та ЛПВЩ (як ФШ), можна припустити наявність зворотного зв'язку між ендогенним тестостероном та концентрацією тригліцеридів і лПнЩ.

При аналізі кореляції тестостерону сироватки та серцево-судинного ризику використовували одномоментні спостереження, що не дозволяють оцінити частоту настання серцево-судинних подій, а лише дозволяють передбачити ймовірність їхнього виникнення. Висновки дослідження базуються на даних, отриманих від 61 обстеженого i, таким чином, вимагають подальшого вивчення в перспективних великомасштабних дослідженнях. 


\section{Огляди літератури, оригінальні дослідження, погляд на проблему}

Висновки. Результати нашого дослідження показали, що для категоризації ризику та прогнозування ймовірності настання серцево-судинних подій у найближчі 10 років у когорті чоловіків із гіпертонічною хворобою, асоційованою з андрогенним дефіцитом, найбільш обґрунтованим $\epsilon$ використання шкали PROCAM.
Перспективи подальших досліджень. У подальших дослідженнях необхідно уточнити роль андрогенного дефіциту в розвитку процесів кардіального та васкулярного ремоделювання у чоловіків із гіпертонічною хворобою.

\section{ЛIТЕРАТУРА}

1. Timmis A. European Society of Cardiology: Cardiovascular Disease Statistics 2017 / A. Timmis, N. Townsend, C. Gale [et al.] // European Heart Journal, ehx628, https:// doi.org/10.1093/eurheartj/ehx628.

2. Щорічна доповідь про стан здоров'я населення, санітарно-епідемічну ситуацію та результати діяльності системи охорони здоров'я України. 2016 рік / МОЗ України, ДУ «УІСД МОЗ України». - Київ, 2017. - 516 с.

3. Testosterone and the cardiovascular system: a comprehensive review of the clinical literature / P. M. Oskui, W. J. French, M. J. Herring [et al.] // J. Am. Heart Assoc. 2013. - No. 2. - e000272.

4. Saad F. The role of testosterone in type 2 diabetes and metabolic syndrome in men / F. Saad // Arq. Bras. Endocrinol. Metabol. - 2009. - Vol. 53. - P. 901-907.

5. Sex hormones and hypertension/R. K. Dubey, S. Oparil, B. Imthum, E. K. Jackson // Cardiovasc. Res. - 2012. No. 53. - P. 688-708.

6. Barton M. Testosterone and secondary hypertension: New pieces to the puzzle / M. Barton, E. R. Prossnitz, M. R. Meyer // Hypertension. - 2012. - No. 59 (6). P. 1101-1103.

7. Serum testosterone levels and arterial blood pressure in the elderly / R. Fogari, P. Preti, A. Zoppi [et al.] // Hypertens. Res. - 2015. - No. 28. - P. 625-630.

8. Investigation, treatment and monitoring of lateonset hypogonadism in males: ISA, ISSAM, EAU, EAA and ASA recommendations / C. Wang, E. Nieschlag, R. Swerdloff [et al.] // Eur. J. Endocrinol. - 2008. - No. 159 (5). P. 507-514.

9. General cardiovascular risk profile for use in primary care: the Framingham Heart Study / R. B. Sr. D'Agostino,

\section{REFERENCES}

1. Timmis, A., Townsend, N., Gale, C., Grobbee, R., Maniadakis, N., \& Flather, M. (2017). European Society of Cardiology: Cardiovascular Disease Statistics 2017. European Heart Journal. doi:10.1093/eurheartj/ehx628

2. Annual report on the health status of the population, the sanitary and epidemiological situation and the results of the Ukrainian health care system in 2016 (2017). Ministry of Health of Ukraine, State Institution "Ukrainian Institute for Strategic Studies of the Ministry of Health of Ukraine", (1), 36-44 [in Ukrainian].

3. Oskui, P.M., French, W.J., Herring, M.J., Mayeda, G.S., Burstein, S., \& Kloner, R.A. (2013). Testosterone and the Cardiovascular System: A Comprehensive Review of the Clinical

R. S. Vasan, M. J. Pencina [et al.] // Circulation. - 2008. No. 117 (6). - P. 743-753.

10. Assmann G. Simple scoring scheme for calculating the risk of acute coronary events based on the 10-year follow-up of the prospective cardiovascular Münster (PROCAM) study / G. Assmann, P. Cullen, H. Schulte // Circulation. 2002. - No. 105 (3). - P. 310-315.

11. Estimation of ten-year risk of fatal cardiovascular disease in Europe: the SCORE project / R. M. Conroy, K. Pyörälä, A. P. Fitzgerald [et al.] SCORE project group // Eur. Heart J. - 2003. - No. 24 (11). - P. 987-1003.

12. Low serum testosterone and increased mortality in men with coronary heart disease / C. J. Malkin, P. J. Pugh, P. D. Morris [et al.] // Heart. - 2010. - No. 96 (22). P. 1821-1825.

13. High serum testosterone is associated with reduced risk of cardiovascular events in elderly men. The MrOS (Osteoporotic Fractures in Men) study in Sweden / C. Ohlsson, E. Barrett-Connor, S. Bhasin [et al.] // J. Am. Coll. Cardiol. - 2011. - No. 58 (16). - P. 1674-1681.

14. In older men, higher plasma testosterone or dihydrotestosterone is an independent predictor for reduced incidence of stroke but not myocardial infarction / B. B. Yeap, H. Alfonso, S. A. Chubb [et al.] // J. Clin. Endocrinol. Metab. - 2014. - No. 99 (12). - P. 4565-4573.

15. Laughlin G. A. Low serum testosterone and mortality in older men / G. A. Laughlin, E. Barrett-Connor, J. Bergstrom // Journal of Clinical Endocrinology and Metabolism. - 2008. - No. 93. - P. 68-75.

16. Plasma testosterone is associated with Framingham risk score / B. Chock, T. C. Lin, C. S. Li, A. Swislocki // The Aging Male. - 2012. - No. 15.

Literature. Journal of the American Heart Association, 2(6), e000272-e000272. doi:10.1161/jaha.113.000272

4. Saad, F. (2009). The role of testosterone in type 2 diabetes and metabolic syndrome in men. Arquivos Brasileiros de Endocrinologia \& Metabologia, 53 (8), 901907. doi:10.1590/s0004-27302009000800002

5. Dubey, R. (2002). Sex hormones and hypertension. Cardiovascular Research, 53 (3), 688-708. doi:10.1016/ s0008-6363(01)00527-2

6. Barton, M., Prossnitz, E.R., \& Meyer, M.R. (2012). Testosterone and Secondary Hypertension: New Pieces to the Puzzle. Hypertension, 59 (6), 1101-1103. doi:10.1161/ hypertensionaha.112.195149 
Огляди літератури, оригінальні дослідження, погляд на проблему

7. Fogari, R., Preti, P., Zoppi, A., Fogari, E., Rinaldi, A., Corradi, L., \& Mugellini, A. (2005). Serum Testosterone Levels and Arterial Blood Pressure in the Elderly. Hypertension Research, 28 (8), 625-630. doi:10.1291/hypres.28.625

8. Ponholzer, A., \& Madersbacher, S. (2009). Re: Christina Wang, Eberhard Nieschlag, Ronald Swerdloff, et al. Investigation, Treatment, and Monitoring of Late-Onset Hypogonadism in Males: ISA, ISSAM, EAU, EAA, and ASA Recommendations. European Urology, 55 (5), e92. doi:10.1016/j.eururo.2008.11.053

9. D'Agostino, R.B., Vasan, R.S., Pencina, M.J., Wolf, P.A., Cobain, M., Massaro, J.M., \& Kannel, W.B. (2008). General Cardiovascular Risk Profile for Use in Primary Care: The Framingham Heart Study. Circulation, 117 (6), 743-753. doi:10.1161/circulationaha.107.699579

10. Assmann, G. (2002). Simple scoring scheme for calculating the risk of acute coronary events based on the 10-year follow-up of the prospective cardiovascular Munster (PROCAM) Study. Circulation, 105 (3), 310-315. doi:10.1161/hc0302.102575

11. Conroy, R. (2003). Estimation of ten-year risk of fatal cardiovascular disease in Europe: the SCORE project. European Heart Journal, 24 (11), 987-1003. doi:10.1016/ s0195-668x(03)00114-3
12. Malkin, C.J., Pugh, P.J., Morris, P.D., Asif, S., Jones, T.H., \& Channer, K.S. (2010). Low serum testosterone and increased mortality in men with coronary heart disease. Heart, 96 (22), 1821-1825. doi:10.1136/ hrt.2010.195412

13. Ohlsson, C., Barrett-Connor, E., Bhasin, S., Orwoll, E., Labrie, F., Karlsson, M. K., ... Tivesten, Å. (2011). High serum testosterone is associated with reduced risk of cardiovascular events in elderly men. Journal of the American College of Cardiology, 58 (16), 1674-1681. doi:10.1016/j. jacc.2011.07.019

14. Yeap, B.B. (2014). In older men, higher plasma testosterone or dihydrotestosterone is an independent predictor for reduced incidence of stroke but not myocardial infarction. The Journal of Clinical Endocrinology \& Metabolism, 99 (12), 4565-4573. doi:10.1210/jc.2014-2664

15. Laughlin, G.A., Barrett-Connor, E., \& Bergstrom, J. (2008). Low serum testosterone and mortality in older men. The Journal of Clinical Endocrinology \& Metabolism, 93 (1), 68-75. doi:10.1210/jc.2007-1792

16. Chock, B., Lin, T., Li, C., \& Swislocki, A. (2012). Plasma testosterone is associated with Framingham risk score. The Aging Male, 15(3), 134-139. doi:10.3109/13685538.20 11.654369

\title{
ОЦЕНКА СЕРДЕЧНО-СОСУДИСТОГО РИСКА У МУЖЧИН С ГИПЕРТОНИЧЕСКОЙ БОЛЕЗНЬЮ НА ФОНЕ АНДРОГЕННОГО ДЕФИЦИТА
}

\author{
๑В. А. Визир, А. С. Садомов, А. В. Насоненко \\ Запорожский государственный медицинский университет
}

РЕзЮМЕ. Введение. Данные многочисленных исследований указывают на связь низкого уровня тестостерона у мужчин с отдельными факторами риска ССЗ (ожирение, сахарный диабет 2 типа, метаболический синдром и т.п.). Статистические подходы предусматривают расчет кардиоваскулярного риска для общей популяции, а использование их для оценки риска у мужчин с дефицитом тестостерона в литературе не описано.

Цель исследования - на основании сравнительного анализа ряда шкал (Фремингемской, SCORE и PROCAM) определить наиболее валидную для оценки сердечно-сосудистого риска у мужчин с гипертонической болезнью на фоне андрогенного дефицита.

Материал и методы. Исследование включало 50 пациентов мужского пола с установленным диагнозом гипертонической болезни II стадии и 11 практически здоровых лиц, вошедших в контрольную группу. У всех участников исследования, наряду с общеклиническим обследованием, определяли параметры липидного профиля и общий тестостерон (ОТ) сыворотки крови, оценивали сердечно-сосудистый риск по Фремингемской шкале (ФШ), шкалам SCORE и PROCAM. В зависимости от уровня ОТ обследованные были поделены на 2 группы: 1 группа ( $n=27)$ - с дефицитом ОТ, 2 группа ( $n=23)$ с нормальным уровнем ОТ.

Результаты. При анализе сердечно-сосудистого риска участников исследования установлено, что по ФШ к группе высокого риска принадлежали 55,6 \% мужчин 1 группы и 43,5 \% лиц 2 группы, по шкале PROCAM риск выше 20 \% имели 66,7 \% и 39,1 \% пациентов соответственно. Доля обследованных, имевших высокий риск по шкале SCORE, составила 51,8 \% среди мужчин 1 группы и 39,1 \% - 2 группы. Значимых различий между риском по ФШ и SCORE между группами 1 и 2 обнаружено не было, в то время как разница между указанными группами была статистически достоверной пошкале PROCAM. Корреляционный анализ показалтенденцию котрицательной обратной связи между сердечно-сосудистым риском и уровнем ОТ, при этом статистически значимой корреляция была только между ОТ и риском по шкале PROCAM ( $<<0,05)$.

Выводы. Использование шкалы PROCAM является наиболее обоснованным для категоризации риска в когорте мужчин с гипертонической болезнью, ассоциированной с андрогенным дефицитом.

КЛюЧЕВЫЕ СЛОВА: гипертензия; тестостерон; холестерин. 


\section{V. A. Vizir, A. S. Sadomov, O. V. Nasonenko \\ Zaporizhzhia State Medical University}

SUMMARY. Data from numerous studies show the correlation of low testosterone in men with certain CVD risk factors such as obesity, type 2 diabetes, metabolic syndrome. Statistical approaches include the calculation of cardiovascular risk for general population, and their use for risk assessment in men with testosterone deficiency is still not well-described in the literature.

The aim of the study - to determine the most valid approach for assessment of cardiovascular risk in hypertensive men with androgen deficiency using the comparative analysis of Framingham, SCORE and PROCAM scales.

Material and Methods. The study included 50 male patients with a diagnosis of stage II hypertension and 11 healthy subjects who were included into the control group. All participants were subjected to the general clinical examination, evaluation of lipid profile and total serum testosterone (TT), cardiovascular risk assessment using Framingham scale (FS), SCORE and PROCAM scales. Depending on the level of TT, the patients were divided into 2 groups: 1 group $(n=27)$ - with testosterone deficiency, 2 group $(n=23)$ with normal TT level.

Results. Analysis of cardiovascular risk of the study participants showed that $55.6 \%$ of men in group 1 and $43.5 \%$ of group 2 had high cardiovascular risk according to FS, while PROCAM risk of over $20 \%$ had $66.7 \%$ and $39.1 \%$ of patients respectively. $51.8 \%$ of men in group 1 and $39.1 \%$ of group 2 were in high risk cohort due to SCORE scale. There was no significant difference between the risk by FS and by SCORE between groups 1 and 2, while the difference between these groups was statistically significant when PROCAM scale was used. Negative correlation was found between cardiovascular risk and TT level, with a statistically significant correlation between TT and PROCAM ( $p<0.05)$.

Conclusions. The use of the PROCAM scale is the most reasonable for categorizing of cardiovascular risk in cohort of hypertensive men associated with androgen deficiency.

KEY WORDS: hypertension; testosterone; cholesterol. 